Review

\title{
PATHOMORPHOLOGICAL ASPECTS OF RELEVANT GASTROINTESTINAL DISEASES IN NEWBORN AND GROWING CALVES
}

\author{
I. Kalkanov*, Iv. Dinev \\ Department of General and Clinical Pathology, Faculty of Veterinary Medicine, Trakia University, \\ Stara Zagora, Bulgaria
}

\begin{abstract}
The emphasis of this literature overview is placed on the etiology, epidemiology, specific gross and microscopic pathological changes of the commonest gastrointestinal diseases in newborn and growing calves in dairy and beef farms. Neonatal diarrhea in calves is a multifactorial disease accompanied with high morbidity and mortality rates. It incurs considerable economic losses for cattle industry worldwide. The gastroenteritis in calves is most commonly of infectious or parasitic etiology and the most frequently involved enteropathogens are Cryptosporidium parvum, bovine rotaviruses (GRA BRV), bovine coronaviruses $(B C o V)$, mucosal disease virus - bovine viral diarrhoea $(B V D V)$ and Escherichia coli $K 99$ (F5). Affected calves are from $24^{\text {th }}$ hours to 30 days of age, and the appearance of the disease is largely dependent on the immunological status of newborn calves, the amount of ingested colostrum, whether dams are vaccinated or not during the dry period, and the conditions of housing of newborns. The specific gross and microscopic lesions of the gastrointestinal tract and of some parenchymal organs are essential for the diagnostics and differential diagnostics of reviewed diseases.
\end{abstract}

Key words: calves, gastroenteritis, neonatal calf diarrhea, pathology

\section{INTRODUCTION}

The increased dairy and beef cattle populations in the world pose a higher risk from the onset and spread of gastrointestinal diseases among newborn and growing calves. At a global scale, this group of diseases is termed neonatal calf diarrhea (NCD) (1). Etiological agents of $\mathrm{NCD}$ are a variety of pathogens as bacteria, viruses, and protozoa, causing diarrhoea in calves either solely or in combination. In calves, gastrointestinal diseases are outlined with high morbidity and mortality rates and are considered to be the main reason for important economic losses for large ruminant farmers in the world. The studies indicate that about $40 \%$ of calves under one month of age show signs of gastrointestinal diseases, which are the main reason for death within this age group (2).

\footnotetext{
*Correspondence to: Ismet Kalkanov PhD, E-mail address:ismet_88@abv.bg,Present address: Department of General and Clinical Pathology Faculty of Veterinary Medicine, Trakia University, 6000 Stara Zagora, Bulgaria, Phone: +35942699566; Mob: +359888452098
}

The rapid death in diseased calves is due to the loss of fluids of electrolytes, resulting in severe dehydration, metabolic acidosis, negative energy balance (3). From historical point of view, the etiology of gastroenteritis in newborn calves is associated with Salmonella spp., E.coli (F5) $\mathrm{K} 99$ and Clostridium perfringens type $C$ (4). In about $30 \%$ of NCD cases, the diagnosis remains uncertain. Some researchers believe that about $64 \%$ of enteritis cases in calves are of infectious origin $(2,3)$. That is why these diseases are determined as multifactorial and dependent on the breed, feeding and rearing conditions. The immunological status of dams in the herd, the occurrence of various infectious agents and farm management are also essential (5).

Recently, bovine noroviruses ( $B N o V)$, bovine neboviruses $(\mathrm{BNeV})$, bovine enteroviruses $(B E V)$ and bovine toroviruses (BToV) were identified as potential agents of enteritis in juvenile calves (6-9). Some of them (BNoV, $B E V$ and $B T o V$ ) have been detected in the faeces of clinical healthy calves as well (10). 
KALKANOV I., et al.

On the basis of epidemiological studies, $B N o V$ and $B T o V$ were reported in faeces of diarrhoeic calves, but their significance in the NCD etiology is still not acknowledged $(5,9)$.

Enteropathogens reported to be most commonly involved in neonatal calf diarrhea at a global scale are: Escherichia coli K99 (F5), bovine viral diarrhoea - mucosal disease virus (BVDV), Cryptosporidium parvum, bovine rotaviruses $(G R A \quad B R V)$ and bovine coronaviruses (BCoV) (11). GRA BRV and $C$. parvum were detected in faeces of calves with gastrointestinal diseases in $17.7 \%$ to $79.9 \%$ of cases (12). Sometimes, co-infections with more than single etiological agents are reported (13).

The prevalence of enterites in cattle farms in the USA varies from $19.1 \%$ and $21.2 \%$ (14). Others (15) affirm than more than $50^{\wedge} \%$ of deaths in non-weaned calves is due to neonatal diarrhoea. Also, the NCD complex includes complicated states such as meningitis and neonatal pneumonia. Outbreaks at farms are frequent, especially when animals have been gathered from different farms with unknown immunological status (16).

The utilisation of combinations of bacteriological and virological methods of examinations along with gross anatomy and histopathological studies of fresh intestinal specimens from diarrhoeic calf carcasses is of upmost importance for detection of the severity and localization of lesions and respective enteropathogens with regard to the diagnosis and differential diagnosis of NCD (17).

\section{COLIBACTERIOSIS}

Coliinfections have a huge economic impact as they affect newborn calves, foals, pigs, lambs and chickens inflicting great losses. Colibacteriosis is an acute infectious disease affecting newborn calves in the first days of their life, manifested with signs of enterocolitis and septicaemia. The disease is caused by the Gramnegative bacterium Escherichia coli. Colibacteria belong to the family Enterobacteriaceae discovered in 1885 by Th. Escherich. The members of this large family are ubiquitous (18).

The main agents of calf diarrhea are strains from several pathovars - enterotoxigaenic E. coli (ETEC), enteropathogenic (EPEC), enteroinvasive (EIEC), diffusely adherent (DAEC) and enterohaemorrhagic (EHEC) E. coli. The first ETEC strain identified in calves is $K 99$ antigen (19).

The pathogenicity of E. coli are also related to the production of haemolysins and substances with necrotic effect. Endotoxins are believed to cause pathological damage of organs and systems: hyperaemia, haemorrhages, vasomotor shock, local and general Shwartzman reaction, fever, increased pulmonary blood pressure, specific dermal reaction, placental damage followed by abortion $(20,21)$.

Diarrhoeic syndrome epidemics in intensive farms is associated to the greater number of susceptible subjects (especially if animals are deprived of the chance to acquire colostrum immunity) and factors facilitating the alimentary transmission mechanisms via the faecal-oral route. In suckling calves, the disease rate is about $30 \%$, but could attain up to $75 \%$, with mortality between 10 and $50 \%$ (22).

ETEC enterites in calves occur as early as on postpartum hour $12-18$ or until the $4^{\text {th }}$ day of life, less frequently in older calves and never in adults. Epidemiological surveys of gastroenteritis in suckling calves have shown that more than $80 \%$ of clinical cases were caused by strains possessing the $K 99$ antigen (23).

The commonest clinical forms of colibacteriosis in calves are three: colisepticaemia, colienterotoxaemia and colienteritis. Mucohaemorrhagic colitis and proctitis are characteristic only for EHEC, but not for EPEC or ETEC, where only the stomach and small intestine are affected (24).

Colisepticaemia is encountered in all animal species and is caused by invasive $E$. coli strains which penetrate in tissues and bloodstream through the intestinal and nasopharyngeal mucosa, the tonsils and umbilical blood vessels. Calves, pigs and lambs with high blood serum immunoglobulin concentrations are usually protected from septicaemia. The clinical signs are due to the produced endotoxin, which causes shock. The disease is most commonly seen in newborn animals which had not been given colostrum (25).

Colienterotoxaemia is caused by enterotoxigaenic $E$. coli strains capable to colonise and replicate in proximal small intestine and to produce enterotoxin. The infection is described in the literature as isocolibacillosis (26). It affects calves during their first week of life, usually in the first 48 hours after birds. The attachment of E. coli to intestinal epithelial cells is done with pilli. The enterotoxic form of colibacteriosis is encountered most commonly in calves and pigs and rarely, in foals and lambs (27). 
Colienteritis (or intestinal form of disease) is caused by colonisation and spread of EPEC, causing diarrhoea, metabolic acidosis and dehydration (28).

Gross anatomy examination showed that the gastrointestinal tract was always affected regardless of the form of colibacteriosis. The intestinal content in most cases is liquid, yellowgreen, of bad odour and mixed with white branlike fibrin flakes. Mesenteric lymph nodes are swollen, juicy and hyperaemic (29).

Macroscopic changes in intestinal colibacteriosis are characterised with dehydration, enlarged intestinal lumen filled with yellow watery content mixed with gas bubbles, and the liver is with a markedly enlarged gallbladder. In affected intestinal compartments, pseudomembranous ileitis, mucohaemorrhagic colitis and proctitis are observed (30).

Histopathological and ultrastructural changes in different segments of the alimentary system of calves with colienteritis have received little attention before due to the impossibility to reproduce the disease in experimental animals. The results from studies performed worldwide showed catarrhal-desquamative inflammation of the abomasum with hyperaemia of propria mисоsae and oedema of submucosa and muscles. In some cases, haematomas in propria mисоsae and bacterial emboli in some submucosal blood vessels were observed. Some authors described adhesion of intestinal villi in the region of the jejunum and ileum with neutrophilic infiltration of the mucosa and numerous attached Gramnegative bacteria (31).

\section{BOVINE VIRAL DIARRHOEA - MUCOSAL DISEASE}

Bovine viral diarrhoea - mucosal disease (Bovine viral diarrhoea virus - $B V D V$ ) is widely prevalent among calves and other ruminants, causing serious economic losses to the cattle breeding sector. The disease is caused by an enveloped virus, $45 \mathrm{~nm}$ in diameter and singlestrand RNA in its genome. It belongs to the Pestivirus genus, family Flaviviridae. From antigenic point of view it is similar to the virus of the classical swine fever (CSFV), border disease in sheep and goats (BDV) and human rubella virus (HRV). $B V D V$ is classified into two biotypes, cytopathic $(C P)$ and non-cytopathic $(N C P)$. Due to its high antigenic variability, it could be placed into two main antigenic groups: type 1 and type 2 . Recently, in Europe was identified also type 3, comprising two subgroups of Thai and Brazilian origin. Type 1 is widely prevalent among ruminants worldwide as well as in Europe, unlike type 2 which is most
KALKANOV I., et al. commonly encountered in the USA, Canada, Japan, South America and some European countries (32).

The disease is characterized with various clinical manifestation of the infection as respiratory diseases, acute or chronic gastrointestinal syndrome in newborn and growing calves, haemorrhagic syndrome with thrombocytopaenia, mucosal disease in cows, skin diseases and immunosuppresion (33).

In pregnant animals the disease causes various reproductive disorders: early embryonic death, abortions, mummified foetuses, foetal malformations, stillbirths, birth of weak and nonvital calves (34). Embryos infected between the $60^{\text {th }}$ and $90^{\text {th }}$ gestational days are born as immunotolerant and persistently infected $(P I)$ calves (35). Congenital malformations have been observed in newborn calves including cerebral hypoplasia, microcephaly, hydrocephaly, osteochondrosis, stunted growth, ocular neuritis, retinal degeneration, hypoplasia of the thymus, hypotrichosis, alopecia, osteosclerosis, microphthalmia and cataract (36). The virus induces degenerative and necrobiotic processes in the myocardium and lungs of intrauterinely infected calves. In sheep and goats, there are data for BVDV infection accompanied with lymphocytic myocarditis and multifocal necroses in the other parenchymal organs (37).

The erosions and shallow ulcers, but not ulcers are usually typical for BVD and the oesophageal lesions in its upper part are also very common instead the lesions in the respiratory system. The epithelium of coronary band and cleft hooves is also affected where interdigital dermatitis and coronitis develop. The BVD virus also has a strong affinity toward lymphatic tissue, especially in the area of tonsils and Peyer's patches, where dystrophic changes in immunocompetent cells and a significant decrease in the amount of lymphocytes in the germinal centers of lymph follicles are seen, which has as a consequence a strong suppression of the cellular and humoral immune response and animal death (37).

Bovine viral diarrhoea (BVD) is a problem for newborn and growing calves and is characterised with haemorrhagic-necrotic and ulcerative lesions on the mucosa of alimentary and respiratory systems (38). There is also a severe acute BVD-type 2, which is characterized by a high morbidity and mortality in all age groups, whereas the "classical bovine viral diarrhea" in calves is 
characterized with a high morbidity and low mortality. Mucosal disease on the other hand is a clinicopathologic syndrome occurring in persistently infected animals commonly aged between 6 months and 2 years, when the virus causing persistent congenital infection spontaneously develops a recombination encoding NS3. The mucosal disease is characterized by low morbidity, but high mortality (38).

The main macroscopic lesions found out in calves having died from mucosal disease BVD were focused in the oral cavity, manifested with gingivitis and multiple erosions and shallow ulcers, mucosal necrosis and haemorrhages. Oesophageal lesions such as linear shallow erosions covered by shreds of necrotic epithelium are also seen most commonly in the upper part of oesophagus. The abomasus, reticulum, omasus, cecum, colon and rectum are also affected with inflammation of a catarrhal to haemorrhagic nature, small erosions, necroses or ulcers. In the chronic cases, the epithelium of coronary band and cleft hooves is affected where interdigital dermatitis and coronitis develop. The lesions in respiratory system are less obvious and only mild tracheitis, bronchitis, and bronchiolitis, which can subsequently progress to secondary bacterial pneumonia, can be seen. The BVD virus also has a strong affinity toward lymphatic tissue, especially in the area of tonsils and Peyer's patches, where dystrophic or necrotic changes in immunocompetent cells and a significant decrease in the amount of lymphocytes in the blood and in the germinal centers of lymph follicles in the spleen and lymph nodes are observed, which has as a consequence a strong suppression of the cellular and humoral immune response and animal death. Occasionally, pleuritis with pulmonary hyperaemia and oedema was present. Microscopically, the myocardium exhibited focal haemorrhages and leukocytic infiltration, and the kidneys lymphoplasmocellular multifocal nephritis. In the brain, neuropathological lesions as neuronophagia and spongiosis of the grey matter of the brain (39).

\section{CRYPTOSPORIDIUM ENTERITIS}

Cryptosporidium spp. (type Apicomplexa, family Cryptosporidiidae) are intracellular extracytoplasmic coccidian protozoa affecting the gastrointestinal tract of a number of mammalian and amphibian species, and in birds - lungs as well (40). Cryptosporidium parvum and Giardia spp. are considered the major protozoan agents involved in calf diarrhoea. Some of the members of the family possess a marked zooanthroponotic potential. Together
KALKANOV I., et al. with some bacterial and viral pathogens, Cryptosporidium parvum is outlined as one of the commonest causative agents of neonatal gastroenteritis in calves up to 3 weeks of age. According to some researchers, the death rate is low but the morbidity rate within the population in the contact environment is high (41).

The most important clinical sign of the disease is the profuse watery diarrhoea of yellow colour, mixed with blood and mucus. The severity and duration of clinical signs depends on the involvement of viruses, bacteria and parasites. The gross appearance of small and large intestine shows that they were distended, filled with gas and watery yellowish fluid, and the mesenteric lymph nodes were enlarged. The intestinal mucosa was strongly hyperaemic and covered with yellowish intestinal content. There were no changes in parenchymal organs $(42,43)$.

Microscopic changes comprised severe atrophy of intestinal villi of the ileum, caecum and the colon (42). Multiple developmental forms of the protozoan bound to epithelial cells lining the ileal villi were observed. The villi were atrophied and rounded, fused one to the other, with cryptic hyperplasia and infiltration by different inflammatory cells. The lamina propria was infiltrated with mononuclear cells, and crypts were distended by the numerous neutrophils. Mesenteric lymph nodes were oedematous, and reticuloendothelial cells - hyperplastic. After a mild infection, no histopathological alterations of intestines were present $(42,44)$.

In clinical cryptosporidiosis outbreaks in calves, multiple developmental forms of the pathogen were established in the middle and distal jejunum and ileum. When the distal small intestine was colonised, the histological finding was manifested as villous atrophy, metaplasia and desquamation of the surface epithelium (42). The authors specified that similar lesions could be also observed in the duodenum, caecum and the colon. They also affirmed that the cellular infiltrate in lamina propria comprised mainly neutrophils (45).

\section{ROTAVIRUS ENTERITIS}

Rotaviruses provoke a number of gastrointestinal diseases in children, calves, piglets, foals, lambs, rabbits, antelopes, mice and exotic animals' species (grizzly bears, kangaroos etc.). Rotaviruses are considered to be among the first identified agents causing diarrhoea in calves under 30 days of age, with prevalence between $10 \%$ and $20 \%$. In some countries, diarrhoea caused by rotaviruses is the main cause for high mortality among children. Group A ( $g p A)$ bovine rotaviruses (GPA $B R V$ ) belong to the family 
KALKANOV I., et al.

Reoviridae with double-strand RNA in their genome, comprising 11 segments (46).

Apart GPA BRV, other enteropathogens as parvoviruses, pestiviruses, caliciviruses, astroviruses and adenoviruses were believed to be involved in intestinal infections of calves (47).

In newborn calves, the infection occurs without viraemic stage, after short incubation period, with profuse diarrhoea combines with severe dehydration. Rotaviruses infect selectively epithelial cells of villi, and the replication of the virus occurs in their cytoplasm with crypts remaining unaffected by the infection. There are data that rotaviruses have been isolated from the lungs and mesenteric lymph nodes of infected calves (48).

After opening of the abdominal cavity, the abomasum and the intestines were ballooned and filled with fluid (49). Also, catarrhal to and rarely catarrhal-haemorrhagic enterocolitis was observed (50).

A number of experiments have proved that small intestinal epithelial cells were the main subject to viral replication despite that viral antigens were found also in the epithelial cells of the colon and caecum of infected calves via immunofluorescence analysis (51).

Histopathological examinations of affected intestinal segments showed shortened villi, and reticular cells were distended with lymphocytic infiltration in the propria and microvilli. Morphological changes were characterised with desquamation of infected cells, followed by severe atrophy of affected villi. Atrophied villi were covered by immature cuboid cells having migrated from crypts (49).

\section{Coronavirus enteritis}

Coronaviruses induce are large enveloped viruses from the family Coronaviridae 100 to $120 \mathrm{~nm}$ in diameter, with a single-stranded RNA. Coronaviruses are divided into 3 groups depending on their source, nucleotide sequence and serological groups $(52,53)$.

$\mathrm{BCoV}$ causes diarrhoea in calves between the $3 \mathrm{rd}$ and 21 st day of life, affecting $11-81 \%$ of the entire herd and often occurs as a mixed infection with rotaviruses. About $60 \%$ of adult cows shed the virus during the winter months. Apart being enterotropic, the $\mathrm{BCoV}$ is also pneumotropic as it is replicated in enterocytes of the gastrointestinal tract and upper respiratory epithelium. In suckling calves, the disease could occur between the $1^{\text {st }}$ and $3^{\text {rd }}$ week of life with peak prevalence 7 to 10 days after birth (54).
In some instances, pneumo-enteritis syndrome is developed, which is clinically manifested with signs of diarrhoea and pneumonia. Clinical signs of $\mathrm{BCoV}$ are more pronounced than those of rotavirus infection due to the more severe mucohaemorrhagic enterocolitis with hyperaemia of the nasal plane and nasal septum - signs of respiratory infection (52).

According to other literature sources, the changes in gastrointestinal tract comprise hyperaemia of the mucosa of the abomasum, caecum, colon and catarrhal-haemorrhagic enterocolitis. Very severe gross changes are established in some foci of the disease, resembling the winder dysentery and mucosal disease in cattle. Also, a pseudomembranous inflammation with multiple haemorrhages on distal colonic mucosa and enlarged mesenteric lymph nodes were observed $(52,55)$.

Coronaviral enteritis is characterised with atrophy of the middle part of villi of both small and large intestine, with damage of cryptic epithelium, which is not present in rotaviral enteritis affecting the upper two-thirds of villi (49). Coronavirus enteritis an atrophy or stripping of the villi of the small intestine are seen, that is often accompanied with some adhesions between the neighboring villiIn conclusion, pathological changes of the alimentary tract induced by $\mathrm{BCoV}$ are more severe than those caused by GPA BRV (54).

Histological changes were more serious in cases of complications with rota- and coronaviruses, enteropathogenic E. coli and Cryptosporidium parvum $(56,57)$.

\section{CONCLUSIONS}

In conclusion, diarrhoea in neonatal and growing calves is a disease entity of various (bacterial, viral, parasitic) etiology and multifactorial nature. The main etiological agents are Escherichia coli K99 (F5), bovine viral diarrhoea - mucosal disease virus (BVDV), Cryptosporidium parvum, bovine rotaviruses (GRA $B R V)$ and bovine coronavirus $(B C o V)$. Coronaviral enteritis is characterised with atrophy of the middle part of villi of both small and large intestine, with damage of cryptic epithelium, which is not present in rotaviral enteritis affecting the upper twothirds of villi (49). In conclusion, pathological changes of the alimentary tract induced by $\mathrm{BCoV}$ are more severe than those caused by GPA BRV (54) and atrophy or stripping of the villi of the small intestine are seen, that is often 
accompanied with some adhesions between the neighboring villi. Necroses in the lymphocytes in the Peyer's patches and regional lymph nodes are also characteristic for coronavirus enteritis in contrast to rotavirus enteritis. The immune status of affected calves is primarily poor and rearing management - inadequate. Losses incurred by farmers at a global scale are huge, due to the high mortality of diseased and reduced weight gain of reconvalescent calves. The establishment of specific gross and histopathological lesions in affected tissues and organs is of utmost significance for the diagnosis and differential diagnosis of these problematic disease states. In all cases, they provide a starting point for elucidation of etiological diagnosis, which takes up more time.

\section{ACKNOWLEDGMENT}

This work aims to focus on etiology, spread, pathological and histopathological changes in the most common gastroenteritis in newborn and adolescent calves.

\section{REFERENCES}

1. Bartels, C., Holzhauer, M., Jorritsma, R., Swart, W. \& Lam, J., Prevalence, prediction and risk factors of enteropathogens in normal and non-normal faeces of young Dutch dairy calves. Prevent Veterinary Medicine, 93:162-169, 2010.

2. Uhde, F., Kaufmann, T., Sager, H., Albini, S., Zanoni, R., Schelling, E., Meylan, M., Prevalence of four enteropathogens in the faeces of young diarrhoeic dairy calves in Switzerland. Veterinary Record, 163:362366.

3. United States Agriculture D.O. Dairy (2007). Part II: Changes in the U.S. Dairy Cattle Industry, 1991-2007, 57-61, 2007.

4. Acha, S., Kuhn

5. I., Jonsson, P., Mbazima, G., Katouli, M. \& Mollby, R., Studies on calf diarrhoea in Mozambique: prevalence of bacterial pathogens. Acta Veterinaria. Scandinavia, 45:27-36, 2004.

6. Milnes, A., Binns, S., Oliver, S. \& Bridger, J., Retrospective study of noroviruses in samples of diarrhoea from cattle, using the Veterinary Laboratories Agency's Farmfile database. Veterinary Record, 160:326-330, 2007.

7. Blas-Machado, U., Saliki, T., Boileau, M., Goens, S., Caseltine, S., Duffy, J. \& Welsh, R., Fatal ulcerative and hemorrhagic typhlocolitis in a pregnant heifer associated with natural bovine enterovirus type-1 infection. Veterinary Pathology, 44:110$115,2007$.
KALKANOV I., et al.

8. Blas-Machado, U., Saliki, T., Sanchez, S., Brown, C., Zhang, J., Keys, D., Woolums, A. \& Harvey, S., Pathogenesis of a bovine enterovirus - 1 isolate in experimentally infected calves. Veterinary Pathology, 48:1075-1084, 2011.

9. Kaplon, J., Guenau, E., Asdrubal, P. \& Pothier, P., Ambert-Balay, K., Possible novel nebovirus genotype in cattle, France. Infection Disease, 17:1120-1123, 2011.

10.Park, S., Oh, E., Park, I., Kim, H., Jeong, Y., Lim, G., Hyun, B., Cho, K., Molecular epidemiology of bovine toroviruses circulating in South Korea. Veterinary Microbiology, 126:364-371, 2008.

11. Mijovski, J., Poljsak-Prijatelj, M., Steyer, A., Barlic-Maganja, D. \& Koren, S., Detection and molecular characterisation of noroviruses and sapoviruses in asymptomatic swine and cattle in Slovenian farms. Infection Evolution, 10:413-420, 2010.

12. Silverlas, C., de Verdier, K., Emanuelson, U., Mattsson, J. \& Björkman, C., Cryptosporidium infection in herds with and without calf diar-rhoeal problems. Parasitology Resurch, 107:1435-1444, 2008.

13. Izzo, M., Kirkland, P., Mohler, V., Perkins, N., Gunn, A. \& House, J., Prevalence of major enteric pathogens in Australian dairycalves with diarrhoea. Australian Veterinary Journal, 89:167-173, 2011.

14. Blanchard, P., Diagnostics of dairy and beef cattle diarrhea. Amimal Food, 28:443-464, 2012.

15.USDA, Dairy 2007 Heifer Calf Health and Management Practices on U.S. Dairy Operations, 2010.

16. Windeyer, M., Leslie, K., Godden, S., Hodgins, D., Lissemore, K. \& LeBlanc, S., Factors associated with morbidity, mortality, and growth of dairy heifer calves up to 3 months of age. Prevent Veterinary Medicine, 113:231-240, 2014.

17. Mailk, S., Kumar, A., Verma, A., Gupta, M., Sharma, S., Sharma, A. \& Rahal, A., Incidence and Drug Resistance Pattern of Collibacillosis in Cattle and Buffalo Calves in Western Uttar Pradesh. Health Production, 1:15-19, 2013.

18. Chigerwe, M., Tyler, J., Summers, M., Middleton, J., Schultz, L. \& Nagy, D., Evaluation of factors affecting serum $\operatorname{IgG}$ concen-trations in bottle-fed calves. Veterinary Medicine Associasion, 234:785789, 2009.

19. Ok, M., Güler, L., Turgut, K., Ok, Ü., Sen, I., Gündüz, I., Birdane, M. \& Güzel-bektes, H., The studies on the aetiology of diarrhoea in neonatal calves and determination of virulence gene markers of Escherichia 
colistrains by multiplex PCR. Zoonoses, 56:94-101, 2009.

20. Azizzadeh, M., Shooroki, H., Kamalabadi, A. \& Stevenson, M., Factors affecting calf mortality in Iranian Holstein dairy herds. Prevent Veterinary Medicine, 104:335-340, 2012.

21.Rahal, A., Kumar, A., Ahmad, A. \& Malik, J., Pharmacokinetics of diclofenac and its interaction with enrofloxacin in sheep. Res in Veterinary Science, 84:452-456, 2007.

22. Rahal, A., Ahmad, A., Kumar, A., Mahima, A., Verma, A., Chakraborty, S. \& Dhama, K., Clinical drug interaction: a holistic view. Biology Science, 16:751-758, 2013.

23.Gulliksen, S., Jor, E. \& Lie, K., Enteropathogens and risk factors for diarrhea in Norwegiandairy calves. Dairy Science, 92:5057-5066, 2009.

24. Garcia-Migura, A., Antimicrobial resistance of zoonotic and commensual bacteria in Europe: The missing link between consumption and resistance in veterinary medicine. Veterinary Microbiology, 170:1-9, 2014.

25.Gay, G., Courtheoux, T., Reyes, C., Tournier, S. \& Gachet, Y., A stochastic model of kinetochore-microtubule attachment accurately describes fission yeast chromosome segregation. The Rockefeller University. Journal Cells Biology, 196(6):757-774, 2012.

26.Ramkumar, P., Evaluation of therapeutic potential of plant extracts against E. coli diarrhoea in calves. MVSc thesis, IVRI Deemed University, Izatnagar, India, 23- 26, 2012.

27.Duda-madej, A. \& Gosciniak, G., Association of untypeable enteropathogenic Escherichia coli (EPEC) strains with persistent diarrhea in children from the region of lower Silesia in Poland. Polish Journal of Microbiology, 62(4):641-644, 2013.

28.Hur, T., Jung, Y., Choe, C., Cho, Y., Kang, S., Lee, H., KS, K., Baek, K., Suh, G., The dairy calf mortality: the causes of calf death during ten years at a large dairy farm in Korea. Korean Journal Veterinary Resurch, 53:103-108, 2013.

29.Lorenz, I., Fagan, J. \& More, S., Calf health from birth to weaning. II. Management of diarrhoea in pre-weaned calves. Irish Veterinary Journal, 64:9-13, 2011.

30.Svensson, C., Lundborg, K., Emanuelson, U. \& Olsson, S., Morbidity in Swedish dairy calves from birth to 90 days of age and individual calf-level risk factors for infectious diseases. Veterinary Medicine, 58:179-197, 2003.

31. Hasina, B., Enteropathotypic characterization of Escherichia coli isolated from diarrhoeic calves and their antibiogram study. M.S. Thesis, Department of Microbiology and Hygiene, BAU, Mymensingh, 68-70, 2006.

32. Uetake, K., Newborn calf welfare: A review focusing. on mortality rates. Animal Science Journal, 84:101-105, 2013.

33. Ridpath, J. \& Flores, E., Flaviviridae. In: Flores E.F. (Ed). Virologia veterinária. Santa Maria: Editora UFSM, 563-591, 2007.

34. Ferreira, L., Flores, E., Driemeier, D., Melo, O. \& Lemos, R., Doença das mucosas associada à dermatite generalizada em bovinos, Mato Grosso do Sul. Pesquisa Veterinária Brasileira, 28(6):285-292, 2008.

35. Flores, E., Weiblen, R., Vogel, F., Roehe, P., Alfieri, A. \& Pituco, E., Infecção pelo vírus da Diarréia Viral Bovina (BVDV) no Brasil histórico, situação atual e perspectivas. Pesquisa Veterinária Brasileira, 25(3):125134, 2013.

36. Arenhart, S., Bauermann, F., Vogel, F., Weiblen, R. \& Flores, E., Evidence of mixed persistent infections in calves born to cows challenged with a pool of bovine viral diarrhea virus isolates. Pesquisa Veterinária Brasileira, 30(12):1053-1057, 2010.

37. Broaddus, C., Lamm, C., Kapil, S., Dawson, L. \& Holyoak, G., Bovine viral diarrhea virus abortion in goats housed with persistently infected cattle. Veterinary Pathology, 46(1):45-53, 2009.

38.Lamm, C., Broaddus, C. \& Holyoak, G., Distribution of bovine viral diarrhea virus antigen in aborted fetal and neonatal goats by immunohistochemistry. Pathology, 46(1):54-58, 2009.

39. Decaro, N., Losurdo, M., Lucente, M., Sciarretta, R., Mari, V., Larocca, V., Elia, G., Cavaliere, N., Martella, V., Fasanella, A. \& Buonavoglia, C., Persistent infection caused by Hobi-like pestivirus. Journal Clinical Microbiology, 51:1241-1243, 2013. http://dx.doi.org/10.1128/JCM.03134-12.

40. Decaro, N., Lanave, G., Lucente, M., Mari, V., Varello, K., Losurdo, M., Larocca, V., Bozzetta, E., Cavaliere, N., Martella, V. \& Buonavogliaa, C., Mucosal Disease-Like Syndrome in a Calf Persistently Infected by Hobi-Like Pestivirus. Journal of Clinical Microbiology, 52(8):2946-2954, 2014.

41.Helmy, M., Ballhaus, C., Fonseca, R., Wirth, R., Nagel, T. \& Tredoux, M., Noble metal nanoclusters and nanoparticles precede mineral formation in magmatic sulfide melts. Nature Communications, 4:24-25, 2013.

42. Chartier, C., Rieux, A., Delafosse, A., Lehebel, A. \& Paraud, C., Detection of Cryptosporidium oocysts in fresh calf faeces: characteristics of two simple tests and evaluation of a semi-quantitative approach. The Veterinary Journal, 198:148-152, 2013. 
43. Kalkanov, I., Dinev, I., Dimitrov, K. \& Iliev, P., Clinical and morphological investigations in a spontaneous Cryptosporidium enteritis outbreak in calves - Case report. Bulgarian Journal of Veterinary Medicine, 1311-1477, 2015. DOI: 10.15547/bjvm.924

44.Becher, K., Robertson, I., Fraser, D., Palmer, D. \& Thompson, R., Molecular epidemiology of Giardia and Cryptosporidium infections in dairy calves originating from three sources in Western Australia. Veterinary Parasitology, 123:1-9, 2004.

45.Kvac, M., Kouba, M. \& Vitovec, J., Agerelated and housing dependence of Cryptosporidium infection of calves from dairy and beef herds in South Bohemia. Czech Republic. Veterinary Parasitology, 137:202-209, 2006.

46. Radostits, O., Gay, C., Hinchcliff, K. \& Constable, P., Diseases associated with protozoa. 10th Edn. In: Veterinary Medicine: A Textbook of Diseases of cattle, horses, sheep, pigs, and goats. Saunders Elsevier, 1483-154, 2008.

47.Haber, P., Patel, M. \& Pan, Y., Intusussception after rotavirus vaccines reported to U.S. VAERS, 2006-2012. Pediatrics, 131:1042-1049, 2013.

48. Dash, S., Tewari, A., Goel, A. \& Bhatia, A., Detection of rotavirus from diarrhoeic cow calves in Mathura, India. Veterinary World, 4(12):554-556, 2011.

49.Kim, H., Park, J., Matthijnssens, J., Lee, J., Bae, Y., Alfajaro, M., Park, S., Kang, M. \& Cho, K., Intestinal and extra-intestinal pathogenicity of a bovine reassortant rotavirus in calves and piglets. Veterinary Microbiology, 152:291-303, 2011.

50.Kalkanov, I., Dinev, I., Aleksandrov, M., Dimitrov, K. \& Zarkov, I., Morphological and Etiological Investigations in A Rotaviral Enteritis Outbreak in Calves. Kafkas University Veteriner Fakultesi Dergisi, 22(2):309-313, 2016.2 DOI: $10.9775 / \mathrm{kvfd} .2015 .14365$
KALKANOV I., et al.

51. Alfieri, A., Parazzi, M., Takiuchi, E. \& Médici, K., Frequency of group A rotavirus in diarrhoeic calves in Brazilian cattle herds, 1998-2002. Tropical Animal Health Production, 38:521-526, 2006.

52.Foster, D. \& Smith, G., Pathophysiology of diarrhea in calves. Vet Clin North Am. Food. Animal Practice, 25(1):13-36, 2009.

53.Zhu, W., Dong, J., Haga, T., Gotom, Y. \& Sueyoshi, M., Rapid and sensitive detection of bovine coronavirus and group a bovine rotavirus from fecal samples by using onestep duplex RT-PCR assay. Journal Veterinary Medicine Science, 73:531-534, 2011.

54. Schroeder, M., Bounpheng, M., Rodgers, S., Baker, R., Black, W., Naikare, H., Velayudhan, B., Sneed, L., Szonyi, B. \& Clavijo, A., Developmen and performance evaluation of calf diarrhea pathogen nucleic acid purification and detection workflow. Journal Veterinary Diagnostic Investigation, 24:945-953, 2012.

55. Rai, R., Hansha, A., Rai, S., Singh, B., Kumar, H., Singh, A., Damodaran, T. \& Dhama, K., Prevalence of rota and coronavirus infections in calves of Barabanki and Raebareli districts of Uttar Pradesh. Indian Jornal Veterinary Pathology, 35:7374, 2011.

56. Thomas, C., Hoet, A. \& Sreevatsan, S., Transmission of bovine coronavirus and serologic responses in feedlot calves under field conditions. American Journal Veterinary Rescue, 67(8):1412-1420, 2006.

57. Gunn, A., Naylor, J. \& House, J., Diarrhea. In: Smith, B.P. (Eds): Large Animal Internal Medicine. Mosby, Elsevier, Louis, 340-363, 2009.

58. Kalkanov, I., Dimitrov K. \& Dinev, I., Clinicomorphological studies in a case of complicated neonatal calf diarrhea. Science \& Technologies, Animal studies \& Veterinary medicine, (4)5:37-43, 2014. 